\title{
Argumentative Questions in an EFL Material: Fostering Students' International Mobility
}

\author{
Carla Richter ${ }^{1}$ \\ IFPB/PPGL UFPE, Instituto Federal da Paraíba, Monteiro, PB, Brazil \\ Julia Larré2 \\ UFRPE/PPGL UFPE, Universidade Federal Rural de Pernambuco, Recife, PE, Brazil
}

Maria Cristina Damianovic ${ }^{3}$

PPGL UFPE, Universidade Federal de Pernambuco, Recife, PE, Brazil

\begin{abstract}
This paper aims at analyzing and categorizing the questions in an EFL teaching material ${ }^{4}$ (RICHTER, 2015), in accordance to the categories created by Ninin (2013). The material was designed for the subject "English for Computer Studies" at a federal university in the northeast of Brazil. We discuss how the questions used in the material provide learners with opportunities to become professionals that act argumentatively and revise their own points of view in the research they developed during the course and outside the classroom. The material, which was designed by the researcher, focuses on the participation of students in international academic events. Grounded in the lineage of Socio-Cultural-Historic Activity Theory (SCHAT) (VYGOTSKY, 1934/2007; LEONTIEV, 1977/1997; ENGESTRÖM, 1987/1999), this paper is based upon the Critical Collaborative Research (CCR) and is fundamentally rooted in Applied Linguistics (LA) for this is a study of language in the Academic realm that promotes changes in the social roles. Questions used in the teaching material (RICHTER, 2015) were analyzed according to categories such as: form, type, nature, thematic conduction and structure (NININ, 2013). Three versions of the same abstract written by students were also examined so as to check how the teaching material questions impacted on learners' writing. Data analysis suggested that the type of questions may contribute to argumentation, to the exhibition of points of view, as well as to the dialogic expansion of knowledge in students' writing. In addition to that, the choice of questions may encourage learners to take part in the dialectic organization of the text. (NININ, 2013).
\end{abstract}

Keywords: Questions; Argumentation; EFL; Teaching material.

\footnotetext{
${ }^{1}$ Master's Degree in Linguistics from the Federal University of Pernambuco, professor of the undergraduate program in Language Arts at Federal Institute of Paraíba. Orcid: https://orcid.org/0000-0003-3537-8700

E-mail: carla.limarichter@gmail.com

${ }^{2} \mathrm{PhD}$ in Linguistics from the Federal University of Pernambuco, professor at the Federal Rural University of Pernambuco and professor of the postgraduate program in Language Arts (Linguistics) at Federal University of Pernambuco. Orcid: https://orcid.org/0000-0001-5863-6931?lang=en E-mail: jlarre1304@gmail.com

${ }^{3} \mathrm{PhD}$ in Applied Linguistics and Language Studies, professor of the postgraduate program in Language Arts (Linguistics) at Federal University of Pernambuco. Orcid: https://orcid.org/0000-00029764-3736
}

E-mail: mcdamianovic@gmail.com 
Título: Perguntas argumentativas em um material didático de ensino de língua inglesa: promovendo a mobilidade internacional dos estudantes

Resumo: Este trabalho tem como objetivo analisar e categorizar as questões de um material didático de uma disciplina de língua inglesa (RICHTER, 2015), de acordo com as categorias criadas por Ninin (2013). O material foi desenvolvido para a disciplina "Inglês na área de Ciências de Computação" em uma universidade federal do nordeste do Brasil. Neste projeto, discutimos como as perguntas usadas no material oferecem aos alunos oportunidades de se tornarem profissionais que agem de forma argumentativa e revisam seus próprios pontos de vista na pesquisa que desenvolveram durante o curso e fora da sala de aula. O material, desenvolvido pela pesquisadora, tem como foco a participação de estudantes em eventos acadêmicos internacionais. Fundamentado na Teoria da Atividade Sócio-Histórico-Cultural (TASHC) (VYGOTSKY, 1934/2007; LEONTIEV, 1977/1997; ENGESTRÖM, 1987/1999), este artigo baseia-se na Pesquisa CríticoColaborativa (PCCol) e é fundamentalmente enraizado na Linguística Aplicada (LA) por este ser um estudo da linguagem no âmbito acadêmico que promove mudanças nos papéis sociais. As questões utilizadas no material didático (RICHTER, 2015) foram analisadas segundo categorias como: forma, tipo, natureza, condução temática e estrutura (NININ, 2013). Três versões do mesmo resumo escrito por alunos também foram examinadas para verificar como as questões do material didático impactaram na escrita dos alunos. A análise dos dados sugeriu que a pergunta, quando bem elaborada, pode contribuir para a argumentação, para a exposição de pontos de vista, bem como para a expansão dialógica do conhecimento na escrita dos alunos. Além disso, a escolha de perguntas pode encorajar os alunos a participar da organização dialética do texto. (NININ, 2013).

Palavras-chave: Perguntas; Argumentação; Ensino de língua inglesa; Material didático.

\section{Introduction}

This article categorizes and examines the rationale behind the questions used in an English as a Foreign Language (EFL) teaching material (RICHTER, 2015) for the discipline "English for Computer Studies" at a federal university in the northeast of Brazil. The main objective of the subject was to prepare students to the social activity (LIBERALI, 2009; 2012; 2013) "taking part in an international academic event" as researchers; therefore, all the questions in the EFL material are related to that.

The research was carried out with a group of twenty Computer Engineering undergraduate students. Initial conversations in class with students showed that most of them were able to read texts in English, but had difficulties in speaking and writing, especially in the academic realm. These abilities, however, were particularly important for a great number of students who were applying for a scholarship in the Science Without Borders ${ }^{5}$ (SWB) program. The genres chosen to be developed in class were "abstract" and "poster presentation". In this case, focal genres are considered the most important ones for effective

\footnotetext{
${ }^{5}$ Science Without Borders was a Brazilian exchange program of scholarships that aimed at promoting the internationalization of Brazilian science and technology through international students' mobility (2011-2014).
} 
participation in the social activity, while orbital genres are relevant, but not necessarily essential for one's engagement in the social activity (LIBERALI, 2009). So, the abstract was chosen as the focal genre, and poster presentation and the orbital one.

Embedded in the Socio-Cultural-Historic Activity Theory (SCHAT) (VYGOTSKY, 1934/2007; LEONTIEV, 1977/1997; ENGESTRÖM, 1987/1999), the social activity "taking part in an international academic event" was chosen due to the multiple possibilities academic events offer to undergraduate students.

The focus on argumentative questions is important for learners to realize both the multiculturalism and the multiple voices that coexist in and outside the classroom (ROJO; MOURA, 2012). Besides that, the work with argumentation in the classroom turns out to be of great value for teachers who meet the challenge of forming a new generation of citizens who, despite conflicts, tensions and drawbacks, work collaboratively to find possible alternatives of action for the social activity they need to perform. In this sense, it is vital that learners should be aware of the importance of making use of internally persuasive discourse (BAKHTIN, 2004) rather than authoritarian arguments.

Argumentation as a dialogue, as we see here facilitates diversity conversation, expands students' points of views, encourages learners to respect everyone's ideas, creates an open mindedness spirit among participants and, finally, fosters the construction of knowledge (LIBERALI, 2013).

Ninin (2013) believes questions may give room to either dialogic expansion (associated with plurality and diversity of voices) or contraction (which does not consider different points of view). According to the author, statements that focus on dialogic expansion provide learners with a wide range of possibilities. The teaching material, in this viewpoint, is an artifact of mediation that offers learners chances to reflect critically upon a certain object.

This paper is organized as follows: after a theoretical framework of the research, we address the concept of argumentation used in this research and its role in SCHAT. Then, we discuss how the questions on the teaching material helped students present their points of view as researchers and expand knowledge towards the social activity.

\section{Theoretical Framework}

Rooted in the legacy of Vygotsky (1934/2007), Leontiev (1977/1997), and more recently in the works of Engeström (1987/1999), the SCHAT is based on socio-historicaldialectical materialism (MARX; ENGELS, 1945/2011), and promotes a straight relation between theory and practice. Sannino, Daniels and Gutiérrez (2009) pose that humans are recurrently engaged in practical social activities, which are part of our daily lives. According to them, it is by taking part in these activities that people develop certain skills, learn how to 
act and behave in society accordingly. Under the perspective of SCHAT, an activity needs to be object-oriented. It means that all the humans engaged in an activity play different roles, follow some rules, make use of mediational tools and act collective and collaboratively, with some purpose(s) in mind so as to fulfill their needs of achieving an object.

In SCHAT, context is usually connected with activities or genres, which are considered mediational tools that learners use to take part in the social activity effectively (RUSSELL, 1999). Influenced by Bakhtin (1997), the concept of genre in SCHAT is associated with the notion of artifacts or instruments that enable individuals to "recognize the activity (...) and act with others over time in more or less but never entirely predictable ways, individually, collectively, and institutionally" (RUSSELL, 1999, p. 43).

Genres also play an important part in constructing the motive of the social activity for they offer learners possibilities to accomplish collective activity and, as a result, fulfill their needs. A vast repertoire of genres help students improvise and innovate while interacting in social activities in real life situations. They broaden learners' communication interactions and enrich their social skills (LIBERALI, 2009).

In this research, specifically, although we worked with a wide range of genres in class, such as: congress homepage, filling in a form, we focused on abstract submission and poster presentation. The reason why the professor chose these genres was because she aimed at genres of the academic realm to enable her students to participate in international events as researchers presenting their own studies. In addition to structural elements that are part of SCHAT (subject, object, community, rules, labor division, tools, sense, meaning and outcome), while designing the teaching material, the teacher wanted students to learn how to argue considering elements such as, collaboration and mutual respect.

Involved in the activity, learners think about ways to transform their social conditions, rewrite new stories for themselves and for others (LARRÉ, 2019). Transformation is a core principle of SCHAT. In SCHAT, people endeavor transformations but there is no transformation without conflicts, contradictions or tension. Davydov (2009) states that the notion of transformation differs from the ordinary concept of change for the first affects an object internally, while the latter alters it externally only. Another key aspect of this perspective concerns the issue of practice. This idea dates from Marx's view of revolutionary practice. According to Davydov (1999), this revolutionary practice is intrinsically associated with intervention and the transformation. The professor's contribution enhanced student's participation in a social activity which enabled them to see themselves with new identities, playing different roles and learning how to change the way they act and behave in academic society.

Another characteristic of SCHAT is the interrelation between theory and practice. This distinctive feature of transformation of SCHAT is justified by the periods of turmoil that researchers have gone through during Russian Revolution in 1917. Sannino, Daniels and Gutiérrez (2009), contextualizing the history of SCHAT, explain that after many years of 
conflicts, Russian intellectuals thought the post-revolution moments were a great opportunity for them to rethink cultural, artistic and scientific life in the country. They also wanted to work collaboratively to make a better world. In this sense, in the educational realm, Vianna and Stentsenko (2014) state that:

From this perspective, educational research always is, and invariably has to be, an activist endeavor too. It is based on researchers and participants working out together and committing to a common project of social transformation that contributes to creating a future viewed by researchers and participants as worthwhile and desirable. (VIANNA AND STETSENKO, 2014, p. 2)

More than the dualism based on subject-object or even grammar rules, appropriate vocabulary use, phonology, and so on, learning a language implies individual transformation and societal change. According to Larré (2010, p. 85), it is possible to say that

(...) human development first takes place from experiences within the social environment in order to be internalized, that is, it is a movement that comes from the exterior to the individual's interior. Collaborative learning takes the knowledge which is inside the individual to outside once more, continuing the intermittent cycle of learning.

Particularly in this research, besides learning how to express themselves as researchers, students were encouraged to work collaboratively in order to expand their knowledge and achieve a goal. From this perspective, everyone is responsible for everybody's learning. As a result, students get more involved in classroom activities and realize that they are interdependent. They learn with and from each other, therefore, knowledge is constructed collectively and expansive learning takes place. Questions can facilitate that if they invite learners to interact in the discourse activity.

Ninin (2013) points out three dimensions that underlie the act of making questions: pragmatic, epistemic and argumentative. The first one has to do with the different ways a language can be used within a social context. Ninin (2013, p. 89) also highlights that several aspects to be taken into account that interfere with the act of questioning, such as: (i) how does the context of action of participants exert influence on discursive actions? (ii) do all participants have access to the topic proposed for discussion? (iii) does the enunciative scenario underline the elements which are part of the context of participants? (iv) do discursive actions legitimate different ideas about the same topic?

The second one is primarily concerned with the ways students construct scientific knowledge in a specific area of study. According to Vargas \& Leitão (2011), epistemic actions help learners transform colloquial into scientific knowledge. In this sense, teachers can make use of questions to help learners to (re)organize academic concepts, ideas or thoughts. 
The argumentative dimension, as might be expected, deals with discursive actions that encourage learners to get engaged in the argumentative movement, presenting arguments, expressing points of view, negotiating meaning and last but not least, (re)constructing and expanding knowledge.

There are many different ways that one can make a question in an academic context, whether in the oral or in the written form. Ninin (2013, p. 102) organizes them according to some aspects related to: form, type, nature, thematic conduction and structure.

Regarding the form (aspectual features), questions may be:

a. matrix questions: when there are tables especially used for short, objective answers;

b. declarative questions: although they are presented as statements, the enunciative context suggests that learners should answer them;

c. interrogative questions: direct or indirect questions that make use of interrogative pronouns;

d. list questions: they involve dichotomous choices (yes/no, true/false, correct/incorrect). In some cases, they present scales or items that have meanings, such as: more, less, a lot, a little);

e. graphic questions: they present images or graphics that demand answers based on these elements;

f. mixed questions: mixed questions use several resources.

As for the type, (characteristics of dialogically expansive or contrastive answers) questions can be:

a. open questions: they provide interlocutors with freedom to choose an answer.

b. closed questions: limit the answer or lead interlocutors to a certain response.

As for the nature, questions can be:

a. ethnographic questions: they deal with one's cultural knowledge;

b. didactic questions: these types of questions have to do with school content. They can be facilitators when they guide learner's discursive action or mediators when they generate conflicts;

c. conditional or hypothetical questions: they raise hypotheses about a certain situation.

Regarding the content, questions can be related to:

a. facts/concepts/actions;

b. meaning;

c. interpersonal relationships/attitudes/behavior/feelings.

As for thematic conduction, questions can be:

a. introductory questions: they are used to introduce the topic; 
b. development questions: they correlate before new information;

c. focal questions: questions used to help students focus on what they are studying;

d. conclusive questions: questions that help students summarize what they have learnt.

As for the structure, questions can be:

a. full questions: the ones which should be effectivelly answered by learners;

b. semi-rhetoric questions: they reinforce what is being asked. The question itself provides readers/interlocutors with possible answers. If you make a semi-rhetoric question, you already know its answer and present it;

c. rhetoric questions: the same as semi-rhetoric questions, the only difference is that the answer is not given;

d. metadiscursive questions: they are used with the purpose of organizing one's thoughts.

In this paper, we will analyze an excerpt of a teaching material and three versions of the same abstract written by a group of Computer Engineering undergraduate students.

\section{Judging a Teaching Material by its "Questions" Rather than its Answers}

The extract below refers to a unit in the teaching material (RICHTER, 2015) that talks about the writing of conference abstracts. Although questions are divided into categories in this paper, they are part of a discursive context that needs to be taken into account if we are to analyze the material properly. The teaching material is dialogic, due to the fact that there is a relation of meaning between the didactic units, they are interdependent and mutually reflective. According to Bakhtin (2002), everyone's discourse is connected with thousands of dialogic threads that constitute his/her own voice as well as other people's discourse. As for the teaching material, there is a closing after each unit and this is necessary for the statement to arouse a responsive active comprehension in the student.

The categorization of the questions from the teaching material is used here as a didactic tool to facilitate the understanding of the role of each question in this teaching material. All the questions are analyzed based on pragmatic, epistemic and argumentative dimensions, as it is possible to observe in the chart below. 
Chart 1 - Writing (Conference) abstracts

\begin{tabular}{|c|c|c|c|c|c|c|}
\hline Question & Form & Type & Nature & Content & $\begin{array}{l}\text { Thematic } \\
\text { conduction }\end{array}$ & Structure \\
\hline $\begin{array}{l}\text { 1.What is a } \\
\text { conference abstract? }\end{array}$ & $\begin{array}{l}\text { Interrogative } \\
\text { question }\end{array}$ & Open & $\begin{array}{l}\text { Didactic } \\
\text { question }\end{array}$ & Concept & $\begin{array}{l}\text { Introductory } \\
\text { question }\end{array}$ & $\begin{array}{l}\text { Full } \\
\text { question }\end{array}$ \\
\hline $\begin{array}{l}\text { 2. What is the main } \\
\text { aim of a conference } \\
\text { abstract? }\end{array}$ & $\begin{array}{l}\text { Interrogative } \\
\text { question }\end{array}$ & Open & $\begin{array}{l}\text { Didactic } \\
\text { question }\end{array}$ & Meaning & $\begin{array}{l}\text { Development } \\
\text { question }\end{array}$ & $\begin{array}{l}\text { Full } \\
\text { question }\end{array}$ \\
\hline $\begin{array}{l}\text { 3. How important is it } \\
\text { for you, as a student? }\end{array}$ & $\begin{array}{l}\text { Interrogative } \\
\text { question }\end{array}$ & $\begin{array}{l}\text { Open; } \\
\text { secondary } \\
\text { question }\end{array}$ & $\begin{array}{l}\text { Ethnographic } \\
\text { question }\end{array}$ & Feelings & $\begin{array}{l}\text { Development } \\
\text { question }\end{array}$ & $\begin{array}{l}\text { Full } \\
\text { question }\end{array}$ \\
\hline $\begin{array}{l}\text { 4. Have you ever } \\
\text { been taught how to } \\
\text { write a conference } \\
\text { abstract? }\end{array}$ & $\begin{array}{l}\text { Interrogative } \\
\text { question }\end{array}$ & $\begin{array}{l}\text { Open; } \\
\text { secondary } \\
\text { question }\end{array}$ & $\begin{array}{l}\text { Ethnographic } \\
\text { question }\end{array}$ & Fact & $\begin{array}{l}\text { Development } \\
\text { question }\end{array}$ & $\begin{array}{l}\text { Full } \\
\text { question }\end{array}$ \\
\hline $\begin{array}{l}\text { 5. Imagine you are } \\
\text { going to submit a } \\
\text { paper to an } \\
\text { important conference } \\
\text { presentation. What } \\
\text { do you have to bear } \\
\text { in mind? Brainstorm } \\
\text { some ideas with your } \\
\text { partner. }\end{array}$ & $\begin{array}{l}\text { Interrogative } \\
\text { question }\end{array}$ & $\begin{array}{l}\text { Open; } \\
\text { summary } \\
\text { question }\end{array}$ & $\begin{array}{l}\text { Hypothetic } \\
\text { question }\end{array}$ & Act & $\begin{array}{l}\text { Development } \\
\text { question }\end{array}$ & $\begin{array}{l}\text { Full } \\
\text { question }\end{array}$ \\
\hline $\begin{array}{l}\text { 6. Read the following } \\
\text { abstracts and analyze } \\
\text { them } 6\end{array}$ & $\begin{array}{l}\text { Declarative } \\
\text { question }\end{array}$ & Open & $\begin{array}{l}\text { Didactic } \\
\text { question }\end{array}$ & Meaning & $\begin{array}{l}\text { Development } \\
\text { question }\end{array}$ & $\begin{array}{l}\text { Full } \\
\text { question }\end{array}$ \\
\hline $\begin{array}{l}\text { 7. Where would you } \\
\text { find these abstracts? }\end{array}$ & $\begin{array}{l}\text { Interrogative } \\
\text { question }\end{array}$ & $\begin{array}{l}\text { Open; } \\
\text { summary } \\
\text { question }\end{array}$ & $\begin{array}{l}\text { Didactic } \\
\text { question }\end{array}$ & Concept & $\begin{array}{l}\text { Development } \\
\text { question }\end{array}$ & $\begin{array}{l}\text { Full } \\
\text { question }\end{array}$ \\
\hline $\begin{array}{l}\text { 8. Do the abstracts } \\
\text { have a title? }\end{array}$ & $\begin{array}{l}\text { Interrogative } \\
\text { question }\end{array}$ & $\begin{array}{l}\text { Closed; } \\
\text { fraudulent } \\
\text { question }\end{array}$ & $\begin{array}{l}\text { Didactic } \\
\text { question }\end{array}$ & Concept & $\begin{array}{l}\text { Development } \\
\text { question }\end{array}$ & $\begin{array}{l}\text { Semi } \\
\text { rhetoric } \\
\text { question }\end{array}$ \\
\hline $\begin{array}{l}\text { 9. How are they } \\
\text { organized? }\end{array}$ & $\begin{array}{l}\text { Interrogative } \\
\text { question }\end{array}$ & $\begin{array}{l}\text { Open; } \\
\text { summary } \\
\text { question } \\
\text { Didactic } \\
\text { question } \\
\end{array}$ & $\begin{array}{l}\text { Ethnographic } \\
\text { question }\end{array}$ & $\begin{array}{l}\text { Structural } \\
\text { question }\end{array}$ & $\begin{array}{l}\text { Development } \\
\text { question }\end{array}$ & $\begin{array}{l}\text { Full } \\
\text { question }\end{array}$ \\
\hline $\begin{array}{l}\text { 10. Are they } \\
\text { interesting and } \\
\text { informative? }\end{array}$ & $\begin{array}{l}\text { Interrogative } \\
\text { question }\end{array}$ & $\begin{array}{l}\text { Closed; } \\
\text { secondary } \\
\text { question; } \\
\text { fraudulent } \\
\text { question }\end{array}$ & $\begin{array}{l}\text { Ethnographic } \\
\text { question }\end{array}$ & Feelings & $\begin{array}{l}\text { Development } \\
\text { question }\end{array}$ & $\begin{array}{l}\text { Semi } \\
\text { rhetoric } \\
\text { question }\end{array}$ \\
\hline $\begin{array}{l}\text { 11. Do they bring the } \\
\text { name of the authors? }\end{array}$ & $\begin{array}{l}\text { Interrogative } \\
\text { question }\end{array}$ & $\begin{array}{l}\text { Closed/ } \\
\text { fraudulent } \\
\text { question }\end{array}$ & $\begin{array}{l}\text { Didactic } \\
\text { question }\end{array}$ & Concept & $\begin{array}{l}\text { Development } \\
\text { question }\end{array}$ & $\begin{array}{l}\text { Semi } \\
\text { rhetoric } \\
\text { question }\end{array}$ \\
\hline
\end{tabular}

${ }^{6}$ http://www.coloradomesa.edu/showcase/documents/math computerscience statistics 2011abst ractexamples.pdf. Access: March 18, 2013. 
Carla Richter, Julia Larré and Maria Cristina Damianovic

\begin{tabular}{|c|c|c|c|c|c|c|}
\hline $\begin{array}{l}\text { 12. Do they have } \\
\text { keywords? What are } \\
\text { they? }\end{array}$ & $\begin{array}{l}\text { Interrogative } \\
\text { question }\end{array}$ & $\begin{array}{l}\text { Closed/ } \\
\text { Open; } \\
\text { fraudulent } \\
\text { question }\end{array}$ & $\begin{array}{l}\text { Didactic } \\
\text { question }\end{array}$ & Concept & $\begin{array}{l}\text { Development } \\
\text { question }\end{array}$ & $\begin{array}{l}\text { Semi } \\
\text { rhetoric / } \\
\text { full } \\
\text { question }\end{array}$ \\
\hline $\begin{array}{l}\text { 13. Do the authors } \\
\text { cite any reference } \\
\text { throughout the texts? }\end{array}$ & $\begin{array}{l}\text { Interrogative } \\
\text { question }\end{array}$ & $\begin{array}{l}\text { Closed } \\
\text { fraudulent } \\
\text { question / }\end{array}$ & $\begin{array}{l}\text { Didactic } \\
\text { question }\end{array}$ & Concept & $\begin{array}{l}\text { Development } \\
\text { question }\end{array}$ & $\begin{array}{l}\text { Semi } \\
\text { rhetoric } \\
\text { question }\end{array}$ \\
\hline $\begin{array}{l}\text { 14. Are the abstracts } \\
\text { clear and concise? } \\
\text { What makes you } \\
\text { think so? }\end{array}$ & $\begin{array}{l}\text { Interrogative } \\
\text { question }\end{array}$ & $\begin{array}{l}\text { Closed/ } \\
\text { fraudulent } \\
\text { question } \\
\text { Open; } \\
\text { polemic } \\
\text { question; } \\
\text { expansive } \\
\text { question }\end{array}$ & $\begin{array}{l}\text { Didactic } \\
\text { question }\end{array}$ & Meaning & $\begin{array}{l}\text { Development } \\
\text { question }\end{array}$ & $\begin{array}{l}\text { Semi } \\
\text { rhetoric; ful } \\
\text { question }\end{array}$ \\
\hline $\begin{array}{l}15 . \text { Would you like to } \\
\text { see any of these } \\
\text { presentations? Justify } \\
\text { your answer. }\end{array}$ & $\begin{array}{l}\text { Interrogative } \\
\text { question }\end{array}$ & $\begin{array}{l}\text { Closed/ } \\
\text { Open; } \\
\text { clarification } \\
\text { question }\end{array}$ & $\begin{array}{l}\text { Didactic } \\
\text { question }\end{array}$ & Feelings & $\begin{array}{l}\text { Development } \\
\text { question }\end{array}$ & $\begin{array}{l}\text { Full } \\
\text { question }\end{array}$ \\
\hline $\begin{array}{l}\text { 16. Choose one of } \\
\text { them and rewrite it. }\end{array}$ & $\begin{array}{l}\text { Declarative } \\
\text { question. }\end{array}$ & $\begin{array}{l}\text { Expansive } \\
\text { question }\end{array}$ & $\begin{array}{l}\text { Didactic } \\
\text { question }\end{array}$ & Meaning & $\begin{array}{l}\text { Conclusive } \\
\text { question }\end{array}$ & $\begin{array}{l}\text { Full } \\
\text { question }\end{array}$ \\
\hline
\end{tabular}

In unit 8, the teacher presented the genre "conference abstracts", students discussed their main characteristics, and learnt about the vocabulary typically used in this genre. In previous lessons students were introduced to the social activity "taking part in an international academic event", whilst the following units were all devoted to the writing of abstracts and posters.

Question 1 ("What is a conference abstract?") introduces the genre "conference abstract". It "opens" the topic and provides students with an opportunity to express their views freely about it. It is a controversial question because it allows a great number of answers and positionings (LIBERALI, 2013).

Question 2 ("What is the main aim of a conference abstract?") has to do with question 1. both are connected and one depends on the other. Students need to have a clear idea of what a conference abstract is in order to answer question 2. It is considered a didactic question because it belongs to the epistemic dimension (NININ, 2013). Students need to know the main aim of a conference abstract if they are to write one. The objective of this question is to systematize knowledge, just like question 1.

Questions 3 ("How important is it for you, as a student?") and 10 ("Are they interesting and informative?") are secondary ones. They are not necessarily relevant for the argumentative movement, but they contribute to the flow of the discussion. They could be dialogic if the teaching material asked students to justify their answers for this would open room to argumentation and to the negotiation of meaning. Question $\mathbf{4}$ is also a secondary one, however it is particularly important for the teacher to plan her next activities because when students answer it, they will talk about their own experiences on the social activity. 
Question 5 ("Imagine you are going to submit a paper to an important conference presentation. What do you have to bear in mind? Brainstorm some ideas with your partner") is a hypothetic question. As it is open, it offers learners an opportunity to present different points of view about the topic, multiple voices may emerge during this discussion. In order to answer this question, students have to use a real situation as reference. By doing so, they generate a conflict. Ninin (2013) believes that this comparison opens room to the creation of new solutions for the problem for there is a question in between the lines: "What do you have to bear in mind when you submit a paper to an important conference presentation?". That is the real question that underlies the original one. In order to answer that question properly, students had to refer back to questions $\mathbf{1}$ and $\mathbf{2}$.

Although Question 6 ("Read the following abstracts and analyze them ...) is not structurally organized as a question, the discursive marker "analyze" suggests students they should reflect on what they have learnt about conference abstracts in order to answer the question and that is why it is considered to be didactic. In many cases in non-academic environments, declarative questions like this do not provoke debate, however the context indicates learners should answer the question (NININ, 2013). There is an epistemic dimension in this question and it helps students to consolidate academic knowledge (LEITÃO, 2011).

Question 7 ("Where would you find these abstracts?") has to do with the enunciative context of the genre. Students need to be aware of that in order to write a conference abstract accordingly. As it is a full question, it may promote discussion. In number $\mathbf{8}$, there is a closed yes/no question that does not expand knowledge. Questions like that do not provoke debate. They are not challenging, on the contrary, they are fraudulent because they lead students to a predictable answer. (NININ, 2013).

In Question 9 ("How are they organized?"), the discourse marker "how" provides students with the chance to express their views. Furthermore, because it is a full question, many students can present their arguments. It could be more dialogically expansive if the teaching material asked learners to justify their answers. Leitão (2011) poses that argumentation takes place in discursive situations when there are different opinions about a topic.

Questions 11 ("Do they bring the name of the authors?"), 12 ("Do they have keywords? What are they?") and $\mathbf{1 3}$ ("Do the authors cite any reference throughout the texts?") are semi-rhetoric ones because the teaching material virtually brings the answer. Question 12 has an illocutionary dimension (NININ, 2013) for when the material asks "what are they?". It clearly suggests there are key words in the abstracts. These types of questions do not explore the (multiple) possibilities of argumentation.

Questions 14 ("Are the abstracts clear and concise? What makes you think so?") and 15 ("Would you like to see any of these presentations? Justify your answer.") indicate that the debate should not be restricted only to the pragmatic dimension. In both cases, students 
need epistemic and argumentative elements to avoid common sense and justify their answers (NININ, 2013). The teaching material invites students to get engaged in discussion through the question "what makes you think so?".

Question 16 ("Choose one of them and rewrite it.") is a declarative one. By reading this statement, students have to refer back to what they have learnt about the topic. It is a conclusive question because it sums up everything seen in class about conference abstracts. It is a full question because it gives room to the plurality of voices and the diversity of ideas in the classroom. (NININ, 2013).

As it can be seen in the analysis of the questions in the teaching material, lexicographical choices made by the material designer play a very importante role in the argumentative movement. The questions may promote the (re)construction of knowledge in a collaborative environment or when they are, they may simply block new points of view about a topic (NININ, 2013).

\section{Questions as a Way to Transform the Learning Process}

The learning process is never a linear one. On the contrary, it is like a spiral movement (VYGOTSKY, 1996). In a polyphonic, multicultural environment, students continuously organize and reorganize their ideas towards learning. They reflect upon spontaneous and scientific knowledge and that is when transformation and critical thinking takes place (FERREIRA, 2013). In this context, questions here are considered symbolic artifacts that help students reflect upon their own learning process.

As material designers, it is only to be expected that teachers should reflect critically about the role of questions in the teaching material, so while planning the teaching material, the professor wondered if it would encourage students to argue in collaborative situations in order to construct and expand knowledge (NININ, 2013).

Furthermore, especially in the social activity "participating in international academic events", abilities like meaning negotiation, argumentative support presentation, argument organization and counter argumentation are crucial for students to learn how to act linguistically as researchers in a poster presentation. In this sense, argumentation departs from conflicts, but it is a lot more than simply persuading others in an authoritative way. Like an arena, there are many voices in the classroom. All of them should be heard for students and teachers learn from each other. This is when transformation begins. In a dialogic movement, students express their opinions, exchange knowledge, argument, counter argument, revisit their initial thoughts, reflect critically and occasionally modify their points of view. This is a unique and enriching process for both teacher and learners.

Questions provide students with opportunities to express their views and share valuable experiences with others. They generate discussion in class, encourage students to 
take risks and engage them in the learning process. Additionally, they contribute to the creation of zones of proximal development or ZPDs throughout the lesson and develop their critical thinking. According to Magalhães (2009, p. 70) the ZPD is a "locus of criticalcollaborative construction" in which each and everyone is responsible for establishing a dialectical relation between theory and practice. In a real collaborative class, students are interdependent. In other words, learners are responsible for each other's knowledge. Lexical evidence collected in the teaching material suggests that learning should be co-constructed by everyone involved in the process. The choice of words also had the same purpose because they have an impact on the reader (NININ, 2013).

According to Ninin (2013, p. 19), questions engage individuals in discursive activity and enable the development of metacognitive thought. They also contribute to the creation of zones of proximal development in which students interact and learn from others. She also suggests that questions/answers in a dialectic-dialogic perspective insert learners in social practice and make them aware of their responsive role in learning. In her words, "students act discursively to make decisions" (NININ, 2013, p. 21).

Ninin (2013) poses that even though questions need answers; it is their linguisticdiscursive features that will dictate how students respond to them in class. In other words, depending on the way teachers make questions, they may encourage learners to participate and get engaged in class discussions, or they may refrain students from expressing themselves freely. That is why it is so important to think about the rationale behind questions in a teaching material.

\section{Results and Discussion}

In the last unit of the teaching material (RICHTER, 2015), students were asked to write an abstract. The activity was done in groups of three because the professor wanted students to discuss the process of writing an abstract. After writing a first version of the abstract, learners were supposed to exchange papers with their peers and had to analyze another group's work. Having done that, students received their abstracts back with comments made by their friends. The activity was particularly useful for students to reflect upon their mistakes, to think about other possibilities for their work and as a result, to enrich their worldview about the writing of abstracts. Students not only produced their own texts but more than that, they were co-authors of their partners' work (LIBERALI, 2013).

In class with students, the professor highlighted the importance of being critical and at the same time open-minded and respectful towards other people's opinion. Argumentation in the lessons required from both teacher and students critical thinking, understanding, belonging, respect and ethics of care (MATEUS, 2016). Concerning the elements mentioned above, Mateus (2016) poses that there is no transformation without them. 
Thus, the creation of a collaborative atmosphere was essential to convey a sense of friendliness and care among learners. In this sense, everybody's opinion mattered for our discourse is not totally ours; it is permeated with other people's voices and words (BAKHTIN, 2014). Because of dialogism, this relation with the other is crucial. We are unfinished social individuals, so, we need to interact with other people in order to know who we are. That is the reason why teacher asked students to exchange information with their partners, instead of simply writing her own comments on the paper. Our incompleteness hinders our ability to see the world without the eyes of the other. New ideas, critical thinking, creative thinking, and the different worldviews of the other are constructed collaboratively. This polyphonic collaborative environment contributes for the construction of knowledge, dialogic expansion and the development of critical thinking.

Furthermore, especially in the social activity "participating in international academic events" abilities like meaning negotiation, argumentative support presentation, argument organization and counter argumentation are crucial for students to learn how to act linguistically as researchers in a poster presentation. In this sense, argumentation departs from conflicts but it is a lot more than simply persuading others in an authoritative way. Like an arena, there are many voices in the classroom. All of them should be heard for students and teachers learn from each other. This is when transformation begins. In a dialogic movement, students express their opinions, exchange knowledge, argument, counter argument, revisit their initial thoughts, reflect critically and occasionally modify their points of view. The chart below illustrates the activity.

Chart 2 - Lesson \#12 (RICHTER, 2015, p. 130)

01. Now it's your turn! Write the first version of your abstract. Having done that, Exchange papers with your friends and write some comments/suggestions for them.

Comments/suggestions:

1.

2.

3.

4.

5. 
In the first draft of the abstract written by students, teacher asked them to share their ideas with their classmates for this would be an enriching process for both teacher and learners. Below, the three drafts of the abstracts written by students:

Chart 3 - First draft (RICHTER, 2015, p. 131) ${ }^{7}$

ANALYSIS OF THE PERFORMANCE OF A GIVEN EVALUATING STRINGS ALGORITHM (ON A REGULAR LANGUAGE)

Checking language is a key factor for many applications in the field of Computer Science, from code compilation (recognition of tokens and syntax in general) to the process of spelling in a text (SIPSER, 2007). Many years ago learning to quantify effectively the balance between the number of processes (threads) and memory consumption to optimize this process was one of the most significant issues of the field. We'd like to know the step by step of a given evaluating strings algorithm (similar to a finite automation) that strictly determines if a string belongs to a regular language established by a formal definition.

Chart 4 - Second draft (RICHTER, 2015, p. 131)

ANALYSIS OF THE PERFORMANCE OF A GIVEN EVALUATING STRINGS ALGORITHM (ON A REGULAR LANGUAGE)

João/Pedro/José ${ }^{8}$

Checking language is a key factor for various applications in the field of Computer Science, from code compilation (recognition of tokens and syntax in general) to the process of spelling in a text (SIPSER, 2007). Many years ago learning to quantify effectively the balance between the number of processes (threads) and memory consumption in order to optimize this process was one of the most significant issues of the field mentioned above (TANEBAUM, 2007). The aim of this research is analyse the performance of a given evaluating strings algorithm (similar to a finite automation) to determine if a string belongs to a regular language established by a formal definition. The sequence of actions of the analysis method consists of an execution of $\mathrm{N}$ copies of the algorithm simultaneously in order to evaluate well-formed sentences in a given text file. The evaluation is

\footnotetext{
${ }^{7}$ The three drafts were written by the students.

${ }^{8}$ For ethical reasons, students' names have been changed.
} 
done by dividing the file in $\mathrm{N}$ pieces. Each one is going to be processed by a copy of the algorithm. After every copy has been successfully executed and its corresponding data is acquired and assorted, the computation of both execution time and memory consumption is finished. This procedure is executed on several computers which consists of diversified hardware using different values of $\mathrm{N}$ so as to achieve data of the algorithm behaviour on distinct processor architectures.

Chart 5 - Third Draft (RICHTER, 2015, p. 132)

ANALYSIS OF THE PERFORMANCE OF A GIVEN EVALUATING STRINGS ALGORITHM (ON A REGULAR LANGUAGE)

João/Pedro/José

Checking language has been thought as a key factor for various applications in the field of Computer Science, from code compilation (recognition of tokens and syntax in general) to the process of spelling in a text (SIPSER, 2007). In the past learning to quantify effectively the balance between the number of processes (threads) and memory consumption to optimize this process was one of the most significant issues of the field. The aim of this research is to analyse the performance of a given evaluating strings algorithm (similar to a finite automation) that strictly determines if a string belongs to a regular language established by a formal definition. The sequence of actions of the analysis method consists of an execution of $\mathrm{N}$ copies of the algorithm simultaneously in order to evaluate well-formed sentences in a given text file. The evaluation is done by dividing the file in $\mathrm{N}$ pieces. Each one is going to be processed by a copy of the algorithm. After every copy has been successfully executed and its correspondent data acquired and assorted, the computation of both execution time and memory consumption is done. This procedure is executed on several computers which consists of diversified hardware using different values of $\mathrm{N}$ so as to achieve data of the algorithm behaviour on distinct processors architectures. The main consequence of this research is the determination of the most efficient quantity of $\mathrm{N}$ threads making use of a thorough observation of the time-memory relationship between algorithm executions.

Keywords: Algorithm, Regular language, Threads, Memory consumption

The first draft has characteristics of oral language, such as "we'd like to know", "step by step" due to the reason that the learners were still getting used to the textual genre, not having learnt all about its formal aspects. It seems to be an adapted oral version of the 
abstract. Vocabulary choices are not appropriate for the discursive construction of the text (LIBERALI, 2013). In terms of thematic conduction, there is no opening, development or an ending. Additionally, the number of words is insufficient for the genre and there are no key words. The second draft is clearly more organized. Students included important elements of an abstract, such as: aim, methodology and keywords. As for the third draft, the structures used by students are more complex, the writing is more formal. The abstract is better organized, there is an introduction, a body of development and an ending. The vocabulary used is more academic and there are keywords (RICHTER, 2015). The final draft is not perfect, but learners made progress from the first to the last one. Although many students spoke English fluently, for many of them it was the first time they wrote an abstract.

\section{Pulling the Trigger: Questions Enhance Argumentative Thinking}

While it is true to say that questions arouse answers, not all of them make students reflect on their responses. Due to the asymmetric relationship between professor and students sometimes learners give answers just for the sake of doing or they may even come up with predictable answers to meet teachers' expectations. When they do so, there is no dialogic expansion or critical thinking, for critical thinking requires metacognition (NININ, 2015). In other words, so as to develop critical thinking, learners should frequently (re)evaluate their own thoughts and ideas. The more they do that, the more critical they get.

The lexical choices observed in the teaching material (Justify your answers, negotiate the answers with your partners, compare your presentation to your classmate's, and so on) were chosen with the purpose of providing students with room for discussion. The questions, especially the open ones gave learners the opportunity to express themselves more freely (NININ, 2013). There is a vast repertoire of questions that teachers can use to encourage students to express their thoughts, arguments and counter arguments. By doing so, learners will be involved in an argumentative movement that will lead to knowledge construction and critical thinking.

Questions will work as a trigger to the multiplicity of voices present in the classroom and will articulate with the collaborative role of argumentation. Although many students (and teachers!) view argumentation as a win/lose situation. In winning/losing situations there is a combative atmosphere, participants focus on identifying each other's mistakes in order to "win" the debate. Collaborative argumentation has to do with "the prospect of creating new possibilities of understanding realities" (LIBERALI, 2012, p.198) and that is why it expands one's knowledge about a topic. (LIBERALI, 2013).

In this sense, teachers should prepare students for this discourse arena because this will be the basis for ideological transformations and autonomous thought (LIBERALI, 2012). Throughout the teaching material (RICHTER, 2015), there are questions that lead students 
towards an argumentative movement (NININ, 2013, p. 77). As we can see in the examples below:

Chart 6 - Argumentative movement in the teaching material

\begin{tabular}{|l|l|l|}
\hline Argumentative element & Definition & $\begin{array}{l}\text { Example in the teaching } \\
\text { material (RICHTER, 2015) }\end{array}$ \\
\hline Positioning & $\begin{array}{l}\text { Learners are asked to express } \\
\text { their points of view. }\end{array}$ & $\begin{array}{l}\text { What is a conference } \\
\text { abstract? }\end{array}$ \\
\hline Justification/Explanation & $\begin{array}{l}\text { Learners are explicitly asked to } \\
\text { justify their answers }\end{array}$ & $\begin{array}{l}\text { Are the abstracts clear and } \\
\text { concise? What makes you } \\
\text { think so? }\end{array}$ \\
\hline Argumentative support & $\begin{array}{l}\text { The core of argumentation. It } \\
\text { should be based on formal } \\
\text { evidence (it can be based on } \\
\text { one's experience or scientific } \\
\text { evidence) }\end{array}$ & $\begin{array}{l}\text { Would you like to see any of } \\
\text { these presentations? Justify } \\
\text { your answer. }\end{array}$ \\
\hline Conclusion & $\begin{array}{l}\text { It is the closing of the } \\
\text { argumentation. End of } \\
\text { discussion. }\end{array}$ & $\begin{array}{l}\text { Have you ever been taught } \\
\text { how to write a conference } \\
\text { abstract? }\end{array}$ \\
\hline Assessment & $\begin{array}{l}\text { Assertion that expresses one's } \\
\text { attitude }\end{array}$ & $\begin{array}{l}\text { Exchange papers with your } \\
\text { friends and write some } \\
\text { comments/suggestions for } \\
\text { them. }\end{array}$ \\
\hline
\end{tabular}

This argumentative movement oriented by questions may generate discursive conflicts and help students organize their opinions. It is also important for them to realize that language is constituted by several voices and they must orchestrate them collaboratively with their peers and the professor so as to revisit and perhaps change their initial thoughts.

\section{General Conclusion, Future Directions}

This paper examined the categories of questions, in accordance to Ninin (2013) in an EFL teaching material especially designed for a Computer Science undergraduate course at a federal university of the northeast of Brazil. The activities were designed to promote collaborative argumentation in class to broaden students' view of the world, to develop argumentative thinking.

Mateus (2013, p. 9) poses that learners should be taught how to argue properly to express their opinions about cultural, economic and political issues. It is also easier to 
participate in discussions and fight for their rights as citizens when one knows how to express his/her opinion with respect and care for diversity.

As mentioned previously, questions, depending on how they are asked may either encourage learners to take part in remarkable, enriching discussions that promote knowledge construction, or they may sound like an authoritarian voice that imposes a correct answer from students.

As we consider teaching materials mediational artifacts that help students develop critical thinking, it is about time teachers reflected on the questions that underlie books and handouts and how they are linguistically organized in the texts.

\section{References}

BAKHTIN, M. Questões de Literatura e Estética: a teoria do romance. 5. ed. São Paulo: Hucitec, 2002.

BAKHTIN, M. (VOLOSHINOV). Marxismo e Filosofia da Linguagem. São Paulo: Hucitec, 2004.

DAVYDOV, V. The Content and unsolved problems of Activity Theory. In: ENGESTRÖM, Y.; MIETTINEN, R.; PUNAMÄKI, R. (Eds, Perspectives on Activity Theory. Cambridge: Cambridge University Press, 1999, p. 39-52. https://doi.org/10.1017/CB09780511812774.004

ENGESTRÖM, Y. Perspectives on Activity Theory. Cambridge: Cambridge University Press, 1999. https://doi.org/10.1017/СBO9780511812774

LARRÉ, J. Inglês nas diversas áreas da universidade: uma possibilidade baseada na argumentação a partir da produção de documentários. Curitiba: Appris, 2019.

LARRÉ, J. Uma trama a várias mãos: a escrita colaborativa na sala de aula de língua inglesa. (Unpublished master's thesis). 2010. Programa de Pós-graduação em Letras (PPGL), UFRPE, Recife. 195 p. Access: 01 jan. 2018. Available in: https://bit.ly/2V5oMEk

LEONTIEV, A. Activity and Consciousness. In: KONSTANTINOV, F. V. Philosophy in the USSR, Problems of Dialectical Materialism (Moscow, 1977, p. 180-202). Available in: Marxists Internet Archive <http://www.marxists.org>. Access: March 07, 2019.

MARX, K.; ENGELS, F. (1945). A ideologia alemã. São Paulo: Centauro, 2011.

FERREIRA, M. Contribuições da teoria sócio-histórico-cultural e da atividade para o ensinoaprendizagem da língua estrangeira. In: LIBERALI, F.; MATEUS, E.; DAMIANOVIC, M. C. (orgs.) A Teoria da Atividade Social Recriando Realidades Sociais. Campinas: Editora Pontes, 2012, p. 61-89.

LEITÃO, S. O lugar da argumentação na construção do conhecimento em sala de aula. In: LEITÃO, S.; DAMIANOVIC, M. (orgs.) Argumentação na escola: O conhecimento em construção. Campinas, SP: Pontes Editores, 2011, p. 13-47.

LIBERALI, F. Argumentation: Tool and object in teacher education. In: MEDRADO, B.; REICHMANN, C. Projetos e práticas na formação de professores de língua inglesa. João Pessoa: 2012, p. 191-227. 
RICHTER, C. Resumos científicos e Apresentação de Pôster em Congresso Internacional: Inglês Acadêmico Além-fronteiras na UFPE. In: Anais do I Seminário Nacional LIGUE: Linguagem, Línguas, Escola e Ensino II Seminário Nacional LAELI: Linguística Aplicada e o Educador De Língua Inglesa Aprender na Atividade Argumentativa Escola-ComunidadeUniversidade, Recife, 2012a, p. 12-13.

RICHTER, C. O ensino da língua inglesa para fins específicos na universidade: a formação do discente - pesquisador. Oral communication presented in II Seminário Internacional de Línguas para Fins Específicos. LINFE. FATEC. São Paulo, 2012b.

RICHTER, C. A linguística aplicada e a TASHC: A performance discente na aula de língua estrangeira na universidade. Seminar presented in II Pocket Symposium: Linguística Aplicada e Análise e Discussão de Dados. UFPE, Recife, 2012 c.

ROJO, R. \& MOURA, E. Multiletramentos na escola. São Paulo: Parábola, 2012.

LIBERALI, F. Argumentação em contexto escolar. São Paulo: Pontes, 2013.

MAGALHÃES, M. A linguagem na formação de professores como profissionais reflexivos e críticos. In: MAGALHÃES, M. (Org). A formação do professor como profissional crítico. Campinas, SP: Mercado das Letras, 2009, p. 45-63.

MATEUS, E. In: LIBERALI, F. Argumentação em contexto escolar. São Paulo: Pontes, 2013.

NININ, M. O. G. Da pergunta como ato monológico avaliativo à pergunta como espaço para expansão dialógica: uma investigação à luz da Linguística Aplicada sobre modos de perguntar. São Carlos: Pedro e João, 2013.

SANNINO, A.; DANIELS, H.; GUTIERREZ, K. Activity theory between historical engagement and future-making practice. In: SANNINO, A.; DANIELS, H.; GUTIERREZ, K. Learning and Expanding with Activity Theory. New York: CUP, 2009. p. 1-19. https://doi.org/10.1017/CBO9780511809989

Recebido em: 27/07/2018

Aceito em: 26/12/2018 